\title{
Applications of Plant Growth Regulators to Container-grown Citrus Trees Affect the Biology and Behavior of the Asian Citrus Psyllid
}

\author{
Antonios E. Tsagkarakis ${ }^{1}$ and Michael E. Rogers \\ Entomology and Nematology Department, University of Florida, Citrus Research and Education \\ Center, 700 Experiment Station Road, Lake Alfred, FL 33850 \\ Timothy M. Spann ${ }^{2}$ \\ Horticultural Sciences Department, University of Florida, Citrus Research and Education Center, \\ 700 Experiment Station Road, Lake Alfred, FL 33850
}

\begin{abstract}
AdDitional INDEX wORDs. Diaphorina citri, huanglongbing, citrus greening, prohexadione calcium
ABstract. Asian citrus psyllid [ACP (Diaphorina citri)] is an important pest of citrus (Citrus sp.) in many citrusgrowing regions of the world because of its status as the vector of huanglongbing disease [HLB (citrus greening)]. There are currently no HLB-resistant citrus genotypes and no proven treatments for the disease; thus, vector control through the use of frequent prophylactic pesticide applications is key to managing the spread of this disease. However, this practice is unsustainable and other means of altering ACP biology or reducing populations are needed. To this end, six plant growth regulators (PGRs) were tested to determine their effect on citrus tree vegetative growth and the subsequent impact on the biology of ACP. In greenhouse and growth chamber experiments, ACP reared on trees treated with prohexadione calcium and mefluidide exhibited significant reductions in both fecundity and survivorship, whereas uniconazole affected only fecundity and paclobutrazol affected only survivorship. No significant effects of PGRs on adult ACP weight were observed except on uniconazole-treated trees. No eggs were laid on dikegulac sodium-treated trees; however, this was likely the result of severe phytotoxicity rather than a true PGR effect. Oviposition rate was lower on all the PGR-treated trees, except chlormequat chloride under greenhouse conditions, compared with untreated control trees. In general, oviposition was delayed on PGR-treated trees compared with untreated controls. The observed changes in ACP biology and behavior after PGR treatment were not the result of a reduction in the number of suitable oviposition sites (i.e., growth reduction) or toxicity of the PGRs to ACP, suggesting there were PGR-induced plant biochemical changes that altered host plant quality. Leaf nutrient analyses and photosynthesis indicated that there were no correlative changes in plant nutrient status or carbon assimilation that led to the changes in ACP behavior, although it is possible that phloem-specific nutrient or carbohydrate changes could have occurred that were not detected in our whole-leaf analyses. These results support previous studies in which the fitness of various insect species has been affected by PGR applications, but more research is needed to understand the changes in plant chemistry that are responsible.
\end{abstract}

Asian citrus psyllid is currently the most important pest in Florida citrus production as a result of its status as the vector of the bacterial pathogen Candidatus Liberibacter asiaticus, the presumed causal agent of HLB. The ACP life cycle is tied to the presence of new shoot growth (flush), which is required for oviposition (egg laying) and nymph development; ACP populations decline during periods of limited or no flush production (Michaud, 2004; Pluke et al., 2008). Mature citrus trees in Florida usually produce two primary growth flushes during the spring and fall, which are important for tree growth and fruit development. Additionally, during summer (the Florida rainy

Received for publication 30 Aug. 2011. Accepted for publication 21 Oct. 2011. Funding for this research was provided by the Florida Citrus Research and Development Foundation.

We thank Luis V. Pozo, Dennys Cornelio, and Harry Anderson for providing capable technical assistance. We also thank Kirsten Pelz-Stelinski and Rajinder Mann for critical evaluation of the manuscript.

Mention of trade names does not imply endorsement by the authors, the University of Florida, or the funding agency but are used solely to provide specific information.

${ }^{1}$ Current address: Laboratory of Agricultural Zoology and Entomology, Agricultural University of Athens, 75 Iera Odos Street, 11855 Athens, Greece.

${ }^{2}$ Corresponding author. E-mail: spann@ufl.edu. season), citrus trees can produce new flush nearly continuously as a result of frequent, often daily, rainfall and warm temperatures (Michaud, 2004; Yuan et al., 2005). These continuous summer flushes allow ACP populations to remain at relatively high levels between the main spring and fall flushes (Tsai et al., 2002) and control with either systemic or contact pesticides is difficult because the new growth rapidly outgrows the protection of the pesticides.

PGRs not only control vegetative growth, but also offer the potential to reduce insect pest populations, especially for groups such as aphids (members of the Aphidoidea) and psyllids (members of the Psyllidae) that are dependent on tender new flushes for reproduction. Negative effects of PGRs on foliarfeeding insects have been demonstrated for several insect pests on various crops. Although the exact modes of action by which PGRs control vegetative growth have not been determined for all PGR compounds, some such as chlormequat chloride have been shown to decrease the soluble nitrogen in some plant species (Linser et al., 1965; van Emden, 1969b; Yule et al., 1966) and this may diminish food quality for phloem-feeding insects such as aphids that are typically nitrogen-limited (Dixon, 1998). Such phloem-feeding insects undergo rapid growth and development but experience delayed development and diminished reproduction 
when nutrient-limited (Bernays and Chapman, 1994; Hosseini et al., 2010; Schoonhoven et al., 2005; van Emden and Wearing, 1965). Chlormequat chloride has been found to reduce the survival and fecundity of several aphid species (Brevicoryne brassicae, Myzus persicae, Aphis nerii, Aphis pomi, Aphis fabae, Acyrthosiphon pisum) (Dreyer et al., 1984; Honeyborne, 1969; Smith, 1969; Tahori et al., 1965; van Emden, 1969a). Similarly, overall reductions in populations of greenhouse whitefly (Trialeurodes vaporariorum) were achieved with applications of chlormequat chloride (Fischer and Shanks, 1979).

In similar studies, mepiquat chloride applied to cotton (Gossypium sp.) reduced cotton bollworm (Helicoverpa zea), cotton jassid (Amrasca biguttula), onion thrips (Thrips tabaci), and sweetpotato whitefly (Bemisia tabaci) infestations (Ahmad et al., 2003; Zummo et al., 1984) and reduced the growth rate of tobacco budworm (Heliothis virescens) (Mulrooney et al., 1985). When used on sorghum (Sorghum bicolor), mepiquat chloride reduced the reproductive rate of the greenbug (Schizaphis graminum) (Dreyer et al., 1984). Westigard et al. (1980) found that the application of daminozide to 'Bartlett' pear (Pyrus communis) resulted in population suppression of the pear psyllid (Cacopsylla pyricola).

These effects may be caused either by a reduction in the volume of vegetative growth or a reduction in its quality as food through alterations in metabolites or nutritional content (Coffelt and Schultz, 1988; Dreyer et al., 1984; Paulson et al., 2005). In addition, PGRs may increase pesticide efficacy by reducing plant growth rates, thereby reducing the "dilution" of systemic insecticides that occurs as new growth is produced or by reducing the physical breakup of surface residues of contact insecticides that occurs on rapidly expanding new leaves (Cooley et al., 1997). As evidence of this, a recent study found a synergistic effect between the PGR prohexadione calcium and the systemic pesticide imidacloprid in the control of the oblique banded leafroller (Choristoneura rosaceana) on apple (Malus $\times$ domestica) and of aphids (C. pyricola and Aphis spiraecola) on pear (Paulson et al., 2005).

In Florida, as a result of high summer temperatures and rainfall, citrus trees produce an excess of vegetative growth beyond what is required to support maximum fruit yield (Yuan et al., 2005). Hedging and topping, the practice of mechanically pruning the sides and top of citrus tree canopies to maintain between-row spacing, are routinely used to control excess growth in Florida orange groves (Lewis and McCarty, 1973; Parsons and Wheaton, 2009). However, this practice can result in undesired vigorous regrowth. Bacon and Bevington (1978) found that hedging early in the spring, similar to current practices for 'Valencia' sweet orange (Citrus sinensis) in Florida, resulted in the production of three growth flushes during the season and that each of these flushes produced longer shoots compared with when hedging was performed in late summer and early fall. In addition, nearly $100 \%$ of pruned shoots regrew when hedged in early spring compared with less than $20 \%$ when hedged in late summer and fall (Bacon, 1981).

Excessive vegetative growth can be problematic in other fruit crops such as apple, where it is routinely managed with the use of PGRs, particularly gibberellic acid (GA) biosynthesis inhibitors (Petracek et al., 2003). In citrus, the use of PGRs has been limited to flower thinning ( $\mathrm{GA}_{3}$ and auxins), improving fruit set $\left(\mathrm{GA}_{3}\right)$, fruit thinning (auxins), and for post-harvest fruit quality $\left(\mathrm{GA}_{3}\right.$, auxins, ethylene) (El-Otmani et al., 2000). Limited research has shown that the GA biosynthesis inhibitors prohexadione calcium (Apogee $\AA$; BASF, Research Triangle Park, NC) (Le Roux and Barry, 2010; Stover et al., 2004) and paclobutrazol (Aron et al., 1985; Delgado et al., 1986; Smeirat and Qrunfleh, 1989) are effective at reducing vegetative growth of citrus; however, these products are not currently used or registered for this purpose in commercial citrus production.

Because the summer flushes provide little benefit in terms of fruit production and tree health (Eissenstat and Duncan, 1992), the use of PGRs to diminish summer flush, and thus ACP populations, may be a useful tactic within an integrated pest management program. We hypothesized that the growth reduction induced by PGR application to citrus would reduce the feeding and oviposition sites available to ACP adults, resulting in a decrease in the number of new ACP on treated trees.

\section{Materials and Methods}

Plant material and cultural conditions. Two experiments were conducted, a greenhouse and growth chamber experiment. The first experiment used 1.5-year-old seedlings of 'Volkamer' lemon (Citrus volkameriana) from late Aug. to midOct. 2009. The trees were grown in an unshaded greenhouse under a natural photoperiod with an average temperature of $29 \pm$ $7{ }^{\circ} \mathrm{C}$ and relative humidity from $70 \%$ to $95 \%$. All trees were grown in 2.65-L Citra-pots (CPOT-5H; Stuewe and Sons, Tangent, OR) using a commercial potting mix composed of peat, pine bark, perlite, and vermiculite (Fafard 2B Mix; Conrad Fafard, Agawam, MA). Trees were $\approx 40 \mathrm{~cm}$ tall at the start of the experiment with multiple branches. Five single-tree replicates were used for each PGR treatment (Table 1), and untreated trees served as controls. Trees with very young "feather" flush (i.e., recently broken buds with new growth $\approx 1-2 \mathrm{~cm}$ in length and immature leaves just beginning to unfold) were selected for use in the experiment. The seedlings had never been treated with systemic insecticides and the last treatment with contact insecticides was greater than 1 year before PGR treatment.

Table 1. Active ingredient chemical name, trade name, manufacturer, and rate of plant growth regulators used to study the effects of applications to Citrus sp. on the reproductive biology of the asian citrus psyllid.

\begin{tabular}{|c|c|c|}
\hline Active ingredient chemical name & Trade name (manufacturer) & Rate $^{z}$ \\
\hline Paclobutrazol & Profile 2SC (SePRO, Carmel, IN) & $0.046 \mathrm{~mL} \cdot \mathrm{L}^{-1}(0.01 \mathrm{~g} /$ a.i. $)$ \\
\hline Dikegulac sodium & Atrimmec (PBI/Gordon) & $16 \mathrm{~mL} \cdot \mathrm{L}^{-1}(3.2 \mathrm{~g} /$ a.i. $)$ \\
\hline Chlormequat chloride & Cycocel (OHP, Mainland, PA) & $16.9 \mathrm{~mL} \cdot \mathrm{L}^{-1}(2.0 \mathrm{~g} / \mathrm{a} . \mathrm{i})$. \\
\hline Prohexadione calcium & Apogee (BASF, Research Triangle Park, NC) & $0.73 \mathrm{~g} \cdot \mathrm{L}^{-1}(0.2 \mathrm{~g} /$ a.i. $)$ \\
\hline
\end{tabular}

${ }^{\mathrm{z}} \mathrm{All}$ rates are based on formulated product; a.i. equivalents are given in parentheses. 
The second experiment was conducted from Jan. to Feb. 2010 and was carried out in a custom-built walk-in growth chamber (Mechanical Refrigeration, Winter Haven, FL) to provide conditions suitable for vegetative growth. The growth chamber was maintained at $28 / 21{ }^{\circ} \mathrm{C}$ day/night temperature with a 14-h photoperiod and a light intensity of 900 $\mu \mathrm{mol} \cdot \mathrm{m}^{-2} \cdot \mathrm{s}^{-1}$ photosynthetically active radiation. Relative humidity was not controlled and averaged $50 \%$ to $70 \%$. PGR treatments were the same as those used in the greenhouse study (Table 1); however, an additional water + adjuvant control was included. For this study, eight 1-year-old 'Valencia' sweet orange trees on 'Kuharske Carrizo' citrange $(C$. sinensis $\times$ Poncirus trifoliata) rootstock were used for each treatment. All plants were grown in 2.65-L Citra-pots using the potting media described previously and were $\approx 70 \mathrm{~cm}$ tall at the start of the experiments. The plants had never been treated with insecticides.

Growth REGULATORS AND APPLICATION TECHNIQUES. The PGR formulations used in the experiments are listed in Table 1. These PGRs were selected because they have been previously shown to be efficacious on citrus (prohexadione calcium and paclobutrazol) or other tree fruit species. All products were applied as foliar sprays to runoff, coating upper and lower leaf surfaces, using a 1-L handheld pump-up sprayer. The soil surface was covered with a cardboard shield during application and was left in place until the products dried to avoid soil contamination and potential root uptake. All sprays included a nonionic surfactant (Induce $\AA$; Helena Chemical Co., Collierville, $\mathrm{TN})$ at $2.5 \mathrm{~mL} \cdot \mathrm{L}^{-1}$. The prohexadione calcium sprays also included $5 \mathrm{~mL} \cdot \mathrm{L}^{-1}$ of $5 \%$ citric acid to aid in product uptake as per the manufacturer's recommendations. Product application rates were selected based on previously published data for citrus (prohexadione calcium and paclobutrazol) or by selecting a recommended label rate for tree use.

Data collection. In both experiments, the total shoot length (sum of the main stem and all lateral branches) of each tree was measured before PGR application and again $32 \mathrm{~d}$ later (after ACP removal). The percent increase in total shoot length was calculated by dividing the difference between the final and initial total shoot length measurements by the initial total shoot length and multiplying the result by 100 .

Seven days after PGR application, a randomly selected pair (one male, one female) of ACP from a colony reared on 'Volkamer' lemon seedlings or 'Valencia' sweet orange trees maintained within psyllid-proof screen enclosures in the greenhouse previously described was caged on each tree. The cages were constructed from a sheet of polyethylene monofilament woven screen with a hole size of $0.266 \times 0.818 \mathrm{~mm}$, which was loosely draped over each tree and secured around the trunk. The number of eggs laid on each plant was counted at 3-d intervals for $21 \mathrm{~d}$. As development of the eggs and then nymphs occurred, the number of nymphs and adults was also counted. Survivorship of nymphs to the adult stage was assessed by dividing the total number of adults after $21 \mathrm{~d}$ (less the two original adults) by the total number of nymphs. Adults were then collected and weighed to determine adult body mass.

To determine if the PGR treatments affected photosynthesis, and thus potentially reduced phloem sap carbohydrate content, instantaneous net $\mathrm{CO}_{2}$ assimilation was measured in the growth chamber experiment on one recently expanded mature leaf on each plant per treatment at 15,25, and $33 \mathrm{~d}$ after treatment using a portable photosynthesis system (LI-6400XT; LI-COR, Lincoln, $\mathrm{NE}$ ) with a $6-\mathrm{cm}^{2}$ broadleaf chamber. The chamber was equipped with an external light-emitting diode light source (6400-02B; $\mathrm{LI}-\mathrm{COR}) \mathrm{set}$ to match the ambient light level $\left(900 \mu \mathrm{mol} \cdot \mathrm{m}^{-2} \cdot \mathrm{s}^{-1}\right)$. In addition, to determine if there were any PGR-induced differences in the nutritional status of the plants, all leaves were removed from each plant at the end of the growth chamber study and sent to a commercial laboratory for complete nutrient analysis (nitrogen, phosphorus, potassium, magnesium, calcium, sulfur, boron, zinc, manganese, iron, and copper; Waters Agricultural Laboratories, Camilla Park, GA).

Statistical analysis. ACP egg counts and adult body weights were natural log-transformed and percent ACP survivorship data were arcsine-transformed to ensure normality, linearity, and homoscedasticity. Differences between treatment means were tested for significance with Tukey's honestly significant difference (HSD) test $(P=0.05)$. Plant nutrient and photosynthesis data and arcsine-transformed percent increase in tree growth data were subjected to one-way analysis of variance. Differences between treatment means were tested for significance with Tukey's HSD test $(P=0.05)$. All analyses were conducted using SAS (Version 9.2; SAS Institute, Cary, NC).

\section{Results}

Plant growth and health. All PGR-treated 'Volkamer' lemon trees grew similar to the untreated control trees, except for dikegulac sodium-treated trees, which grew significantly less than the untreated control trees (Fig. 1A). In the second experiment, both the paclobutrazol and dikegulac sodiumtreated trees grew significantly less than the untreated control trees (Fig. 1B). All other PGR treatments on the 'Valencia' trees had growth similar to the untreated control trees, except for

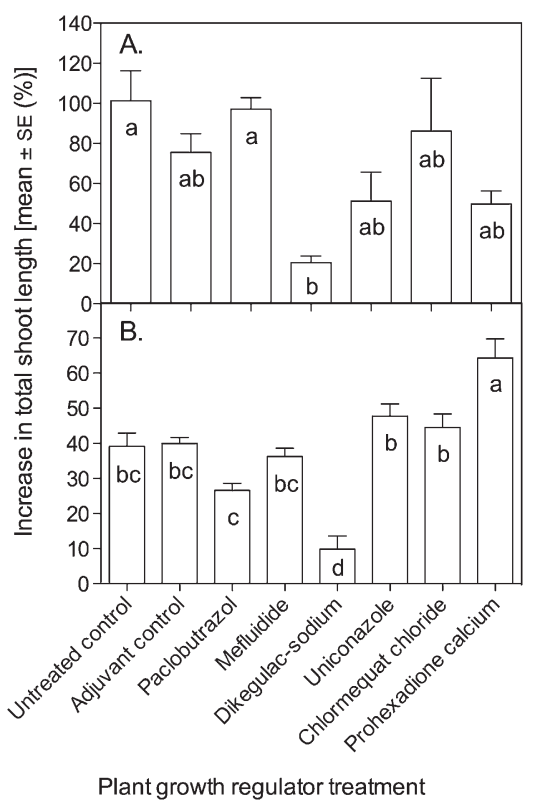

Fig. 1. Increase in total shoot length for 'Volkamer' lemon (A) and 'Valencia' sweet orange (B) trees 4 weeks after treatment with different plant growth regulators and grown under greenhouse conditions $\left(29 \pm 7{ }^{\circ} \mathrm{C}\right.$, relative humidity from $70 \%$ to $95 \%$, natural light and photoperiod) or growth chamber conditions $\left(28 / 21{ }^{\circ} \mathrm{C}\right.$ day/night, relative humidity $50 \%$ to $70 \%, 14-\mathrm{h}$ photoperiod and $900 \mu \mathrm{mol} \cdot \mathrm{m}^{-2} \cdot \mathrm{s}^{-1}$ photosynthetically active radiation), respectively. Lowercase letters indicate statistically significant differences among means by Tukey's honestly significant difference test $[\mathrm{n}=5$ ('Volkamer'), $\mathrm{n}=8$ ('Valencia'), $P=0.05$ ]. 
prohexadione calcium-treated trees, which grew significantly more than the untreated control trees. Some phytotoxicity symptoms, primarily leaf chlorosis, were observed in both studies on plants treated with mefluidide, paclobutrazol, and uniconazole, but these symptoms were transient. However, dikegulac sodiumtreated trees in both studies exhibited severe phytotoxicity symptoms, manifested as a severe chemical burn of all new flush present at the time of treatment.

Net $\mathrm{CO}_{2}$ assimilation measured at three times during the growth chamber experiment revealed no significant differences among any of the treatments, averaging $4.48 \mu \mathrm{mol} \cdot \mathrm{m}^{-2} \cdot \mathrm{s}^{-1}(P=$ $0.9116), 2.34 \mu \mathrm{mol} \cdot \mathrm{m}^{-2} \cdot \mathrm{s}^{-1}(P=0.4927)$, and $5.07 \mu \mathrm{mol} \cdot \mathrm{m}^{-2} \cdot \mathrm{s}^{-1}$ $(P=0.3508)$ at 15,25 , and $33 \mathrm{~d}$ after treatment, respectively.

There were no significant differences in leaf tissue concentrations of magnesium, boron, or manganese among any of the treatments (Table 2). The adjuvant-only treatment had the lowest leaf concentrations of nitrogen, phosphorus, and potassium compared with the untreated control trees, but there were no significant differences between any of the PGR treatments and the untreated control trees. Interestingly, calcium concentration was lowest in the prohexadione calcium-treated trees; however, it was only significantly lower compared with the adjuvanttreated control trees, dikegulac sodium, and uniconazole treatments. Sulfur concentration was lowest in the untreated and adjuvant-treated control trees but was only significantly different relative to the uniconazole-treated trees. Zinc concentration was significantly greater for dikegulac sodium, uniconazole, chlormequat chloride, and prohexadione calcium-treated trees relative to paclobutrazol and mefluidide-treated trees and both the untreated and adjuvant-treated control trees. Copper concentration in the dikegulac sodium-treated trees was significantly greater than all other treatments. Iron concentration was lowest in paclobutrazol and mefluidide-treated trees but was only significantly different compared with dikegulac sodiumand uniconazole-treated trees.

ASIAN CITRUS PSYLLID FECUNDITY. There were differences in both the total number of eggs laid and the pattern of oviposition in both the greenhouse and growth chamber experiments. In the greenhouse study, oviposition began immediately after the ACPs were caged on the untreated and chlormequat chloride-treated trees with eggs being present at the first counting $3 \mathrm{~d}$ after caging (Fig. 2A). Oviposition did not begin until between 6 and $9 \mathrm{~d}$ after caging for prohexadione calcium and paclobutrazol-treated trees and not until between 9 and $12 \mathrm{~d}$ after caging for mefluidide and uniconazole-treated trees. The maximum oviposition rate was 29.4 eggs/plant per day and occurred on chlormequat chloridetreated trees between Days 12 and 15 after caging (Fig. 2A). No eggs were laid on the dikegulac sodium-treated trees, likely because of the severe phytotoxicity. After $21 \mathrm{~d}$, paclobutrazol, mefluidide, uniconazole, and prohexadione calciumtreated trees had significantly fewer total eggs laid compared with the untreated control and chlormequat chloride-treated trees (Fig. 2A).

Results were similar in the growth chamber study. Oviposition began immediately after caging on both the untreated and adjuvant control trees with eggs being present at $3 \mathrm{~d}$ after caging (Fig. 2B). Oviposition was delayed until between 3 and $6 \mathrm{~d}$ after caging for paclobutrazol and chlormequat chloride-treated trees and until between 12 and $15 \mathrm{~d}$ after caging for mefluidide, uniconazole, and prohexadione calcium-treated trees. The

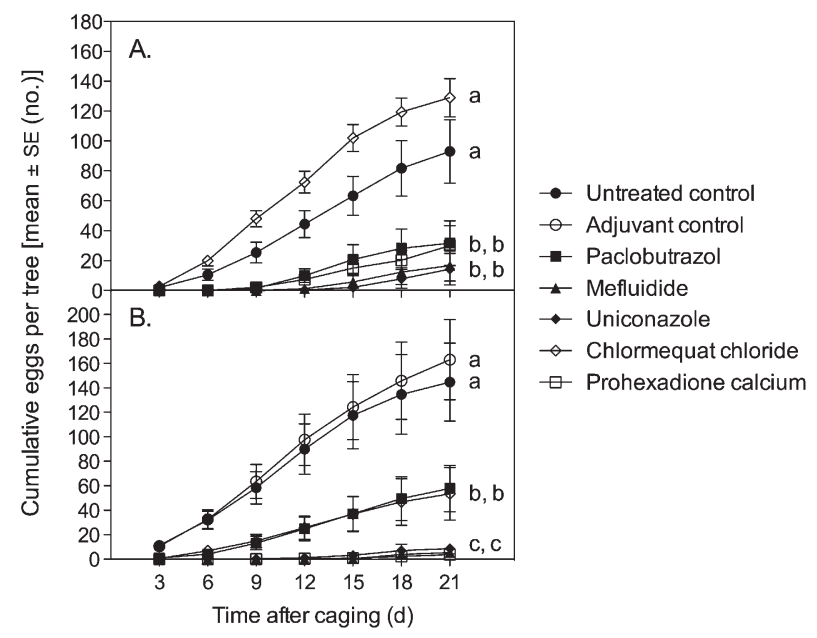

Fig. 2. Cumulative number of eggs laid per tree, counted at 3-d intervals over 21 d, by asian citrus psyllids reared on 'Volkamer' lemon (A) or 'Valencia' sweet orange $(\mathbf{B})$ trees treated with different plant growth regulators and grown under greenhouse conditions $\left(29 \pm 7{ }^{\circ} \mathrm{C}\right.$, relative humidity from $70 \%$ to $95 \%$, natural light and photoperiod) or growth chamber conditions $\left(28 / 21{ }^{\circ} \mathrm{C}\right.$ day/ night, relative humidity $50 \%$ to $70 \%, 14-\mathrm{h}$ photoperiod and $900 \mu \mathrm{mol} \cdot \mathrm{m}^{-2} \cdot \mathrm{s}^{-1}$ photosynthetically active radiation), respectively. Lowercase letters indicate statistically significant differences among means of total number of eggs laid (day 21) by Tukey's honestly significant difference test $(\mathrm{n}=5, P=0.05)$. There was no adjuvant control treatment applied to the 'Volkamer' lemon trees $(\mathbf{A})$.

Table 2. Effect of different plant growth regulator treatments on the leaf nutrient concentrations of 'Valencia' sweet orange trees grown under growth chamber conditions $\left(28 / 21{ }^{\circ} \mathrm{C}\right.$ day/night, relative humidity $50 \%$ to $70 \%, 14$-h photoperiod and $900 \mu \mathrm{mol} \cdot \mathrm{m}^{-2} \cdot \mathrm{s}^{-1}$ photosynthetically active radiation) for $21 \mathrm{~d} .^{\mathrm{z}}$

\begin{tabular}{|c|c|c|c|c|c|c|c|c|c|c|c|}
\hline \multirow[b]{2}{*}{ Treatment } & Nitrogen & Phosphorus & Potassium & Calcium & Magnesium & Sulfur & Boron & Zinc & Copper & Manganese & Iron \\
\hline & \multicolumn{6}{|c|}{ Leaf concn (\%) } & \multicolumn{5}{|c|}{ Leaf concn $\left(\mu \mathrm{g} \cdot \mathrm{g}^{-1}\right)$} \\
\hline Untreated control & $4.41 \mathrm{a}^{\mathrm{y}}$ & $0.24 \mathrm{ab}$ & $2.42 \mathrm{bc}$ & $1.74 \mathrm{bc}$ & $0.29 \mathrm{NS}$ & $0.51 \mathrm{~b}$ & $47 \mathrm{NS}$ & $57 \mathrm{c}$ & $21 \mathrm{~b}$ & $164 \mathrm{NS}$ & $211 \mathrm{ab}$ \\
\hline Adjuvant control & $3.94 \mathrm{~b}$ & $0.19 \mathrm{c}$ & $2.33 \mathrm{c}$ & $1.83 \mathrm{ab}$ & 0.31 & $0.48 \mathrm{~b}$ & 36 & $59 \mathrm{bc}$ & $11 \mathrm{c}$ & 154 & $134 \mathrm{~b}$ \\
\hline Mefluidide & $4.39 \mathrm{a}$ & $0.22 \mathrm{abc}$ & $2.44 \mathrm{bc}$ & $1.68 \mathrm{bc}$ & 0.31 & $0.51 \mathrm{ab}$ & 41 & $68 \mathrm{~b}$ & $12 \mathrm{c}$ & 176 & $123 \mathrm{~b}$ \\
\hline Dikegulac sodium & $4.69 \mathrm{a}$ & $0.23 \mathrm{ab}$ & $2.51 \mathrm{ab}$ & $1.94 \mathrm{ab}$ & 0.28 & $0.54 \mathrm{ab}$ & 46 & $81 \mathrm{a}$ & $36 \mathrm{a}$ & 171 & $262 \mathrm{a}$ \\
\hline Uniconazole & $4.64 \mathrm{a}$ & $0.22 \mathrm{abc}$ & $2.46 \mathrm{abc}$ & $2.10 \mathrm{a}$ & 0.30 & $0.57 \mathrm{a}$ & 46 & $86 \mathrm{a}$ & $24 \mathrm{~b}$ & 185 & $252 \mathrm{a}$ \\
\hline Prohexadione calcium & $4.30 \mathrm{ab}$ & $0.24 \mathrm{a}$ & $2.60 \mathrm{a}$ & $1.59 \mathrm{c}$ & 0.30 & $0.50 \mathrm{~b}$ & 37 & $82 \mathrm{a}$ & $18 \mathrm{~b}$ & 154 & $191 \mathrm{ab}$ \\
\hline
\end{tabular}

${ }^{\mathrm{z}}$ Leaves were sampled $28 \mathrm{~d}$ after plant growth regulator application $(\mathrm{n}=8)$.

${ }^{y}$ Lowercase letters indicate statistically significant differences within columns by Tukey's honestly significant difference test $(P=0.05)$. NS = nonsignificant. 
maximum oviposition rate was 34.1 eggs/plant per day and occurred on the adjuvant-treated control trees between Days 9 and 12 after caging (Fig. 2B). Like in the greenhouse experiment, no eggs were laid on dikegulac sodium-treated trees. After $21 \mathrm{~d}$, significantly fewer eggs were laid on all PGR-treated trees compared with the untreated and adjuvant-treated control trees with mefluidide, uniconazole, and prohexadione calcium having significantly fewer eggs laid than paclobutrazol and chlormequat chloride-treated trees (Fig. 2B).

IMMATURE ASIAN CITRUS PSYLLID SURVIVORSHIP AND ADULT WEIGHT. Only paclobutrazol significantly reduced ACP nymph to adult survivorship in the greenhouse study (Table 3). However, because there were significantly fewer eggs laid on all PGR-treated trees, except chlormequat chloride, there were significantly fewer adults produced on these trees, although survival was generally unaffected (data not shown). Adult weight did not differ significantly for any of the treatments relative to the untreated control trees; however, it did vary significantly among treatments and ACP that developed on uniconazole-treated trees had the lowest adult weight (Table 3).

In the growth chamber experiment, paclobutrazol did not reduce ACP nymph to adult survivorship as it did in the greenhouse experiment, but mefluidide and prohexadione calcium did (Table 4). Again, although some treatments did not reduce survivorship, the reduced number of eggs laid on PGR-treated trees significantly reduced the total number of adults on those trees (data not shown). Similar to the greenhouse study, ACP adult weight did not differ significantly for any of the PGR treatments relative to the untreated or adjuvant-treated control trees; however, there were significant differences among PGR treatments and ACP that developed on uniconazole-treated trees had the lowest adult weight (Table 4).

\section{Discussion}

In general, the 'Volkamer' lemon trees were less responsive to all PGR treatments than the 'Valencia' trees. This is could be the result of factors such as application rate or timing or the difference in vigor of 'Volkamer' lemon (Castle et al., 1989; Zekri, 2000), which had a 100\% increase in total shoot length for control trees, compared with 'Valencia', which had only a $40 \%$ increase in total shoot length for control trees over the same time period. Differences in genotype response to PGR treatments are not uncommon. In studies with prohexadione calcium, Garner et al. (2010) found that shoot growth of 'Eureka' lemon (Citrus limon) was more sensitive than 'Washington' navel orange (C. sinensis). Yelenosky et al. (1995) found that the vegetative growth of six different citrus rootstock varieties treated with paclobutrazol was variably reduced by $40 \%$ to $70 \%$ depending on genotype. Similarly, Barrett and Nell (1989) found that 'Bright Golden Anne' chrysanthemum (Chrysanthemum $\times$ morifolium) was more sensitive to both paclobutrazol and uniconazole compared with 'Pert' chrysanthemum.

Five of the six PGRs tested in this study are GA biosynthesis inhibitors. Chlormequat chloride is an onium compound that acts early in the GA biosynthetic pathway by inhibiting the cyclization of geranylgeranyl pyrophosphate to copallyl pyrophosphate (Davis and Curry, 1991). Mefluidide acts slightly later in the biosynthetic pathway than chlormequat chloride by inhibiting the biosynthesis of ent-kaurenol (Wilkinson, 1982). Paclobutrazol and uniconazole act at a similar point in the GA biosynthetic pathway as mefluidide and inhibit the oxidation of
Table 3. Effect of different plant growth regulator (PGR) treatments on the survival and adult weight of asian citrus psyllid (ACP) reared on 'Volkamer' lemon trees under greenhouse conditions $\left(29 \pm 7{ }^{\circ} \mathrm{C}\right.$, relative humidity from $70 \%$ to $95 \%$, natural light and photoperiod) for $21 \mathrm{~d}$.

\begin{tabular}{lcc}
\hline PGR treatment & Survival $(\%)^{\mathrm{z}}$ & Avg adult ACP wt $(\mathrm{mg})^{\mathrm{y}}$ \\
\hline Untreated control & $45.2 \mathrm{a}^{\mathrm{x}}$ & $0.50 \mathrm{abc}$ \\
Paclobutrazol & $6.5 \mathrm{~b}$ & $0.61 \mathrm{a}$ \\
Mefluidide & $67.7 \mathrm{a}$ & $0.51 \mathrm{ab}$ \\
Dikegulac sodium & $\mathrm{ND}^{\mathrm{w}}$ & $\mathrm{ND}$ \\
Uniconazole & $36.1 \mathrm{ab}$ & $0.41 \mathrm{c}$ \\
Chlormequat chloride & $72.7 \mathrm{a}$ & $0.47 \mathrm{bc}$ \\
Prohexadione calcium & $46.9 \mathrm{a}$ & $0.51 \mathrm{ab}$ \\
\hline
\end{tabular}

${ }^{\mathrm{z}}$ Survival was calculated by dividing the difference between the total number of eggs laid and the number of adult ACP that developed by the total number of eggs.

${ }^{y}$ At least 20 adult ACP were weighed from each treatment to determine average adult weight.

${ }^{x}$ Lowercase letters indicate statistically significant differences within columns by Tukey's honestly significant difference test $(P=0.05)$.

${ }^{\mathrm{w}} \mathrm{ND}=$ no data. Severe phytotoxicity in this treatment prevented oviposition, thus no survival or adult weight data were collected.

Table 4. Effect of different plant growth regulator (PGR) treatments on the survival and adult weight of asian citrus psyllid (ACP) reared on 'Valencia' sweet orange trees under growth chamber conditions $\left(28 / 21{ }^{\circ} \mathrm{C}\right.$ day/night, relative humidity $50 \%$ to $70 \%, 14-\mathrm{h}$ photoperiod and $900 \mu \mathrm{mol} \cdot \mathrm{m}^{-2} \cdot \mathrm{s}^{-1}$ photosynthetically active radiation) for $21 \mathrm{~d}$.

\begin{tabular}{lcc}
\hline PGR treatment & Survival $(\%)^{\mathrm{z}}$ & Avg adult ACP wt $(\mathrm{mg})^{\mathrm{y}}$ \\
\hline Untreated control & $74.3 \mathrm{a}^{\mathrm{x}}$ & $0.50 \mathrm{abc}$ \\
Adjuvant control & $74.2 \mathrm{a}$ & $0.51 \mathrm{abc}$ \\
Paclobutrazol & $61.5 \mathrm{ab}$ & $0.56 \mathrm{a}$ \\
Mefluidide & $28.7 \mathrm{bc}$ & $0.52 \mathrm{ab}$ \\
Dikegulac sodium & $\mathrm{ND}^{\mathrm{w}}$ & $\mathrm{ND}$ \\
Uniconazole & $40.9 \mathrm{abc}$ & $0.42 \mathrm{c}$ \\
Chlormequat chloride & $52.0 \mathrm{ab}$ & $0.47 \mathrm{bc}$ \\
Prohexadione calcium & $26.4 \mathrm{c}$ & $0.51 \mathrm{abc}$
\end{tabular}

${ }^{\mathrm{z}}$ Survival was calculated by dividing the difference between the total number of eggs laid and the number of adult ACP that developed by the total number of eggs.

${ }^{y}$ At least 20 adult ACP were weighed from each treatment to determine average adult weight.

${ }^{\mathrm{x}}$ Lowercase letters indicate statistically significant differences within columns by Tukey's honestly significant difference test $(P=0.05)$.

${ }^{\mathrm{w}} \mathrm{ND}=$ no data. Severe phytotoxicity in this treatment prevented oviposition, thus no survival or adult weight data were collected.

kaurene, kaurenol, and kaurenal to kaurene oxidase (Davis and Curry, 1991). Prohexadione calcium functions much later in the GA biosynthetic pathway, inhibiting the $3 \beta$-hydroxylation of inactive GAs (e.g., $\mathrm{GA}_{20}$ ) to active GAs (e.g., GA G $_{1}$ (Radamacher, 2000). Dikegulac sodium is not known to affect the GA biosynthetic pathway directly but disrupts cell wall development in meristems acting as a chemical pinching agent and is also known to alter endogenous hormone levels, including abscisic acid- and GA-like substances and ethylene (Davis and Curry, 1991).

Relatively little data are available on the effects of GA on photosynthesis. The exogenous application of $\mathrm{GA}_{3}$ has been found to stimulate photosynthesis in wheat [Triticum sp. (Ashraf et al., 2002)] and broad bean (Vicia faba) and soybean 
(Glycine max) (Yuan and Xu, 2001) but reduces photosynthesis in Plantago major (Dijkstra et al., 1990). In an attempt to clarify the effect of GA on photosynthesis Biemelt et al. (2004) developed transgenic tobacco (Nicotiana tabacum) lines with elevated and reduced levels of endogenous GA. They found that the lines with reduced levels of endogenous GA had higher instantaneous leaf photosynthetic rates but reduced whole-plant photosynthetic rates because of the reduced leaf area per plant. The opposite was true for the lines with elevated endogenous GA levels where leaf photosynthetic rates were lower but whole-plant photosynthesis was higher. We found no significant differences in instantaneous leaf photosynthetic rates among any of the treatments in our study; however, we did not measure total leaf area so we cannot make estimations of whole-plant photosynthetic rates, which may have been affected.

PGR effects on horticultural crops are often discussed with respect to growth, but there are relatively few data available with respect to their effects on plant nutrient content, which could be of great importance in the context of insect pest interactions. Atkinson (1986) theorized that PGRs could increase nutrient content by essentially concentrating nutrients as a result of reduced growth. Alternatively, he suggests that PGRs may reduce nutrient content by affecting nutrient uptake as a result of reduced stomatal conductance and water uptake. In the present study, the changes in nutrient content associated with PGR treatment were relatively few with zinc being the only nutrient affected by the majority of the PGRs tested. Although some nutrient concentration changes were statistically significant, it is unlikely they were of biological significance because all nutrient concentrations for all treatments were well within the established optimum range for citrus (Obreza and Morgan, 2008).

Optimal ACP egg production has been demonstrated to occur at $28^{\circ} \mathrm{C}$ and survival of the third through fifth instars was unaffected by temperatures from $15-28{ }^{\circ} \mathrm{C}$ (Liu and Tsai, 2000). Temperatures in our greenhouse study often exceeded these optima (average $29 \pm 7{ }^{\circ} \mathrm{C}$ ), but were well within them for the growth chamber study $\left(28 / 21{ }^{\circ} \mathrm{C}\right.$ day/night). That said, the number of eggs laid and survivorship on control plants in both studies was high, indicating that the greenhouse and growth chamber environmental conditions were not a limiting factor for oviposition. In both studies, PGR treatment, with the exception of chlormequat chloride in the greenhouse study, apparently reduced the quality of the trees as a host for ACP as measured by the total number of eggs laid. The results of this study generally agree with previous studies on the effects of PGRs on other insects in other crop systems. El-Ibrashy and Mansour (1970) demonstrated that chlormequat chloride reduced larval growth and pupal weight of black cutworm (Agrotis ypsilon) on castor bean leaves (Ricinus communis). Honeyborne (1969) and van Emden (1964, 1969a, 1969b) also observed a reduction in aphid reproductive rate on broad beans, oleander (Nerium oleander), and apples treated with chlormequat chloride. Visscher (1980) found that both GA and abscisic acid added to a grass diet significantly reduced the fecundity, egg viability, and, thus, the rate of reproduction of the grasshopper Aulocara elliotti, although the concentrations used were unusually high compared with the natural endogenous levels of these hormones.

Differences in the fecundity, oviposition patterns, survival, and adult weight of ACP in the present study could be a direct effect of PGRs on insect fitness such as toxicity or a reduction in the number of suitable oviposition sites or an indirect effect such as a reduction in the quality of the host plant. There was no mortality observed among any of the ACP pairs caged on the trees in either study, suggesting that the PGR treatments were not directly toxic. However, it is possible that there could be different toxicity sensitivities between adult and immature ACP. This is suggested by the effects of paclobutrazol (greenhouse study) and mefluidide and prohexadione calcium (growth chamber study) on immature survivorship, but these effects were not consistent between the two experiments, warranting further study.

Dikegulac sodium was the only PGR tested that unquestionably directly affected ACP biology by reducing oviposition sites. The severe phytotoxicity of this chemical severely limited new shoot growth (required for ACP oviposition) on treated trees in both studies, and new, undamaged growth was just beginning to emerge near the conclusion of the studies. Although some of the other PGRs reduced vegetative growth relative to the untreated controls (albeit not significantly in most cases), our observations indicate that there was still sufficient new growth to support ACP reproduction. This is supported by the fact that mefluidide-treated trees grew similar to untreated control trees in the greenhouse and growth chamber experiments, yet oviposition was reduced by $80 \%$ and $95 \%$, respectively. Also, prohexadione calcium and uniconazole significantly reduced growth only in the greenhouse experiment but significantly reduced oviposition in both experiments.

There were no significant differences in adult ACP weight between any of the PGR treatments and the untreated controls; however, there were significant differences among the PGR treatments with uniconazole treatment consistently producing the smallest ACP adults in both studies. Similar decreases in adult weight of aphids reared on PGR-treated plants have been correlated with decreases in essential dietary nutrients, particularly nitrogen (N) (van Emden, 1969b; van Emden and Wearing, 1965; Yule et al., 1966), but this does not appear to be the case in our study based on the nutrient data collected in the growth chamber experiment. In this experiment, nutrient analysis of leaf tissues revealed that leaf $\mathrm{N}$ concentration was significantly reduced only in the adjuvant-treated control plants on which ACP displayed a high rate of oviposition and survivorship. ACP, a phloem-feeder, mainly ingests $\mathrm{N}$ through free amino acids in the phloem. It is possible that phloem $\mathrm{N}$ as amino acids may not correlate with the total leaf $\mathrm{N}$ measured here. PGR-induced changes in phloem free amino acid content have been correlated with reproduction and survivorship of aphids (Honeyborne, 1969).

The reduction in the number of eggs laid by ACP adults in the current study does not appear to be attributable primarily to a reduction in plant growth as hypothesized with the exception of dikegulac sodium-treated trees. Similarly, leaf nutrient content as measured in this study does not correlate with changes in ACP biology. Although we did not analyze leaf or phloem sap carbohydrate content in this study, photosynthesis data did not reveal any differences in carbon assimilation among any of the treatments. However, it is possible that PGR treatments could have altered source-sink relationships and, thus, carbohydrate availability without affecting photosynthesis. These results suggest that a PGR-induced plant biochemical change affecting the suitability of the citrus trees as hosts for ACP such as phloem amino acid changes may have been the primary cause of ACP fitness changes. The application of PGRs to citrus trees had an overall negative effect on ACP fitness by reducing 
fecundity, oviposition rate, survivorship, and/or adult weight, but apparently not through the growth reduction mechanism hypothesized. Further studies are needed to elucidate the cause of these changes, determine the duration of efficacy, and whether negative effects on ACP fitness can be achieved in the field without detrimental effects on tree health or yield before PGRs can be pursued as a tool for use in citrus-integrated pest management programs.

\section{Literature Cited}

Ahmad, N., S.M.M.S. Rashdi, and A.A. Rajput. 2003. Efficacy of plant growth regulators to manage the insect pests of cotton. Asian J. Plant Sci. 2:544-547.

Aron, Y., S.P. Monselise, R. Goren, and J. Costo. 1985. Chemical control of vegetative growth in citrus trees by paclobutrazol. HortScience 20:96-98.

Ashraf, M., F. Karim, and E. Rasul. 2002. Interactive effects of gibberellic acid $\left(\mathrm{GA}_{3}\right)$ and salt stress on growth, ion accumulation and photosynthetic capacity of two spring wheat (Triticum aestivum L.) cultivars differing in salt tolerance. Plant Growth Regulat. 36:49-59.

Atkinson, D. 1986. Effects of some plant growth regulators on water use and the uptake of mineral nutrients by tree crops. Acta Hort. 179:395-404.

Bacon, P.E. 1981. The effect of hedging time on regrowth and flowering of mature Valencia orange trees. Aust. J. Agr. Res. 32: 61-68.

Bacon, P.E. and K.B. Bevington. 1978. Effect of timing of hedging on shoot growth and flowering in citrus. 1978 Proc. Intl. Soc. Citriculture 1:314-316.

Barrett, J.E. and T.A. Nell. 1989. Comparison of paclobutrazol and uniconazole on floriculture crops. Acta Hort. 251:275-280.

Bernays, E.A. and R.F. Chapman. 1994. Host-plant selection by phytophagous insects. Chapman and Hall, New York, NY.

Biemelt, S., H. Tschiersch, and U. Sonnewald. 2004. Impact of altered gibberellin metabolism on biomass accumulation, lignin biosynthesis, and photosynthesis in transgenic tobacco plants. Plant Physiol. 135:254-265.

Castle, W.S., D.P.H. Tucker, A.H. Krezdorn and C.O. Youtsey. 1989. Rootstocks for Florida citrus. Coop. Ext. Serv., Univ. of Florida, Inst. Food Agr. Sci. SP42.

Coffelt, M.A. and P.B. Schultz. 1988. Influence of plant growth regulators on the development of the azalea lace bug (Hemiptera: Tingidae). J. Econ. Entomol. 81:290-292.

Cooley, D., J. Gamble, and W. Autio. 1997. Summer pruning as a method of reducing flyspeck disease on apple fruit. Plant Dis. 81:1123-1126.

Davis, T.D. and E.A. Curry. 1991. Chemical regulation of vegetative growth. Crit. Rev. Plant Sci. 10:151-188.

Delgado, R., R. Casamayor, J.L. Rodgriguez, P. Cruz, and R. Fajardo. 1986. Paclobutrazol effects on oranges under tropical conditions. Acta Hort. 179:537-544.

Dijkstra, P., H. Ter Reegen, and P.J.C. Kuiper. 1990. Relation between relative growth rate, endogenous gibberellins and the response to applied gibberellic acid for Plantago major. Physiol. Plant. 79:629634.

Dixon, A.F.G. 1998. Aphid ecology: An optimization approach. Chapman \& Hall, London, UK.

Dreyer, D.L., B.C. Campbell, and K.C. Jones. 1984. Effect of bioregulator-treated sorghum on green bug fecundity and feeding behavior: Implications for host-plant resistance. Phytochemistry 23:1593-1596.

Eissenstat, D.M. and L.W. Duncan. 1992. Root growth and carbohydrate responses in bearing citrus trees following partial canopy removal. Tree Physiol. 10:245-257.

El-Ibrashy, M.T. and M.H. Mansour. 1970. Hormonal action of certain biologically active compounds on Agrotis ypsilon larvae. Experientia 26:1095-1096.
El-Otmani, M., C.W. Coggins, M. Agustí, and C.J. Lovatt. 2000. Plant growth regulators in citriculture: World current uses. Current Rev. Plant Sci. 19:395-447.

Fischer, S.J. and J.B. Shanks. 1979. Whitefly infestation on chrysanthemum and poinsettia treated with plant and insect growth regulators. J. Amer. Soc. Hort. Sci. 104:829-830.

Garner, L.C., Y. Zheng, T. Khuong, and C.J. Lovatt. 2010. Prohexadionecalcium affects shoot growth of evergreen subtropical woody perennials differently than deciduous temperate zone woody perennials-Is it a case of apples and oranges? Acta Hort. 884:249-256.

Honeyborne, C.H.B. 1969. Performance of Aphis fabae and Brevicoryne brassicae on plants treated with growth regulators. J. Sci. Food Agr. 20:388-390.

Hosseini, M., A. Ashouri, A. Enkegaard, S.H. Goldansaz, M.N. Mahalati, and V. Hosseininaveh. 2010. Performance and population growth rate of the cotton aphid, and associated yield losses in cucumber, under different nitrogen fertilization regimes. Intl. J. Pest Mgt. 56:127-135.

Le Roux, S. and G.H. Barry. 2010. Vegetative growth responses of citrus nursery trees to various growth retardants. HortTechnology 20:197-201.

Lewis, L.N. and C.D. McCarty. 1973. Pruning and girdling in citrus, p. 211-219. In: Reuther, W. (ed.). The citrus industry, Vol. III (revised ed.). Univ. of California, Riverside, CA.

Linser, H., K.H. Neumann, and H. El Damaty. 1965. Preliminary investigation of the action of (2-chloroethyl)-trimethyl ammonium chloride on the composition of the soluble $\mathrm{N}$-fraction and the protein fraction of young wheat plants. Nature 206:893-895.

Liu, Y.H. and J.H. Tsai. 2000. Effects of temperature on biology and life table parameters of the asian citrus psyllid, Diaphorina citri Kuwayama (Homoptera: Psyllidae). Ann. Appl. Biol. 137:201-206.

Michaud, J.P. 2004. Natural mortality of asian citrus psyllid (Homoptera: Psyllidae) in central Florida. Biol. Control 29:260-269.

Mulrooney, J.E., P.A. Hedin, W.L. Parrott, and J.N. Jenkins. 1985. Effects of PIX, a plant growth regulator, on allelochemical content of cotton and growth of tobacco budworm larvae (Lepidoptera: Noctuidae). J. Econ. Entomol. 78:1100-1104.

Obreza, T.A. and K.T. Morgan. 2008. Nutrition of Florida citrus trees. 2nd Ed. Florida Coop. Ext. Serv., Gainesville, FL.

Parsons, L.R. and T.A. Wheaton. 2009. Tree density, hedging and topping. Coop. Ext. Serv., Univ. of Florida, Inst. Food Agr. Sci. HS1026. 23 Nov. 2011. <http://edis.ifas.ufl.edu/hs290>.

Paulson, G.S., L.A. Hull, and D.J. Biddinger. 2005. Effect of a plant growth regulator prohexadione-calcium on insect pests of apple and pear. J. Econ. Entomol. 98:423-431.

Petracek, P.D., F.P. Silverman, and D.W. Greene. 2003. A history of commercial plant growth regulators in apple production. HortScience 38:937-942.

Pluke, R.W.H., J.A. Qureshi, and P.A. Stansly. 2008. Citrus flushing patterns, Diaphorina citri (Hemiptera: Psyllidae) populations and parasitism by Tamarixia radiata (Hymenoptera: Eulophidae) in Puerto Rico. Fla. Entomol. 91:36-42.

Radamacher, W. 2000. Growth retardants: Effects on gibberellin biosynthesis and other metabolic pathways. Annu. Rev. Plant Physiol. Plant Mol. Biol. 51:501-531.

Schoonhoven, L.M., J.J.A. van Loon, and M. Dicke. 2005. Insectplant biology. Oxford University Press, Oxford, UK.

Smeirat, N. and M. Qrunfleh. 1989. Effect of paclobutrazol on vegetative and reproductive growth of 'Lisbon' lemon. Acta Hort. 239:261-264.

Smith, B.D. 1969. Spectra of activity of plant growth regulators against various parasites of one host species. J. Sci. Food Agr. 20:398-400.

Stover, E.W., S.M. Ciliento, and M.E. Myers. 2004. Response of six citrus genotypes to prohexadione-Ca. Plant Growth Regulat. Soc. Amer. Qrtly. 32:86.

Tahori, A.S., A.H. Halevy, and G. Zeidler. 1965. Effect of some plant growth regulators on the feeding of the cotton leafworm. J. Sci. Food Agr. 16:570-572. 
Tsai, J.H., J.-J. Wang, and Y.-H. Liu. 2002. Seasonal abundance of the asian citrus psyllid, Diaphorina citri (Homoptera: Psyllidae) in southern Florida. Fla. Entomol. 85:446-451.

van Emden, H.F. 1964. Effect of (2-chloroethyl)-trimethyl ammonium chloride on the rate of increase of the cabbage aphid [Brevicoryne brassicae (L.)]. Nature 201:946-948.

van Emden, H.F. 1969a. Plant resistance to Myzus persicae induced by a plant regulator and measured by aphid relative growth rate. Entomol. Exp. Appl. 12:125-131.

van Emden, H.F. 1969b. Plant resistance to aphids induced by chemicals. J. Sci. Food Agr. 20:385.

van Emden, H.F. and C.H. Wearing. 1965. The role of the aphid host plant in delaying economic damage levels in crops. Ann. Appl. Biol. 56:323-324.

Visscher, N.S. 1980. Regulation of grasshopper fecundity, longevity and egg viability by plant growth hormones. Experientia 36:130131.

Westigard, P.H., P.B. Lombard, R.B. Allen, and J.G. Strang. 1980. Pear psylla: Population suppression through host plant modification using daminozide. Environ. Entomol. 9:275-277.

Wilkinson, R.E. 1982. Mefluidide inhibition of sorghum growth and gibberellin precursor biosynthesis. J. Plant Growth Regul. 1:85-95.
Yelenosky, G., J.C.V. Vu, and H.K. Wutscher. 1995. Influence of paclobutrazol in the soil on growth, nutrient elements in the leaves, and flood/freeze tolerance of citrus rootstock seedlings. J. Plant Growth Regul. 14:129-134.

Yuan, L. and D.Q. Xu. 2001. Stimulation effect of gibberellic acid short-term treatment on leaf photosynthesis related to the increase in Rubisco content in broad bean and soybean. Proc. Natl. Acad. Sci. USA 92:6640-6644.

Yuan, R., F. Alferez, I. Kostenyuk, S. Singh, G. Zhong, J. Syvertsen, and J. Burns. 2005. Partial defoliation can decrease average leaf size but has little effect on orange tree growth, fruit yield and juice quality. HortScience 40:2011-2015.

Yule, W.N., E.V. Parups, and I. Hoffman. 1966. Toxicology of planttranslocated malic hydrazide. Lack of effects on insect reproduction. J. Agr. Food Chem. 14:407-409.

Zekri, M. 2000. Evaluation of orange trees budded on several rootstocks and planted at high density on flatwoods soil. Proc. Florida State Hort. Soc. 113:119-123.

Zummo, G.R., J.H. Benedict, and J.C. Segers. 1984. Effect of the plant growth regulator mepiquat chloride on host plant resistance in cotton to bollworm (Lepidoptera: Noctuidae). J. Econ. Entomol. 77:922924. 